\title{
The Influence of Religiosity toward Costumers 'Decision Making in Choosing Bank Riau Kepri Sharia Tembilahan Kota, Indonesia (Transformation of Conventional Consumer Behavior Theory, Kotler - Armstrong)
}

\author{
$1^{\text {st }}$ Hansen Rusliani ${ }^{1}, 2^{\text {nd }}$ Rafidah $^{2}, 3^{\text {rd }}$ Nur Syam $^{3}, 4^{\text {th }}$ Suryani $^{4}, 5^{\text {th }}$ Muhammad Lathoif Ghozali $^{5}$, \\ $6^{\text {th }}$ Nur Kholis ${ }^{6}, 7^{\text {th }}$ Iskandar Ritonga $^{7}, 8^{\text {th }}$ Rokhmat Subagiyo ${ }^{8}$ \\ \{hansenrusliani@gmail.com¹,rafidah_era@uinjambi.ac.id², nursyam7@yahoo.co.id ${ }^{3}$, \\ taqi_77@yahoo.com ${ }^{4}$, muhammadlathoif@gmail.com ${ }^{5}$, nurkholis08@gmail.com ${ }^{6}$, \\ iskandarritonga999@gmail.com ${ }^{7}$, mat97.eca@gmail.com $\left.{ }^{8}\right\}$
}

Universitas Islam Negeri STS Jambi ${ }^{1,2}$, UINSA Surabaya ${ }^{3,4,5,6,7}$, UIN Sayyid Ali Rahmatullah Tulungagung ${ }^{8}$

\begin{abstract}
The research aims to achieve the objectives of analyzing the extent of the influence of religiosity towards decision making to be a customer of Bank Riau Kepri Sharia, Indonesia. This reseach used explanatory quantitative, intended to explain the relationship among variables to examine a hypothesis. The population of this study is all customers of Bank Riau Kepri Sharia in year 2021. A total samples are 205 respondents, to determine the sample using multivariate analysis Jhon Hair. In order to answer the problems formulated in this study using Structural Equation Modeling (SEM) is conducted. Based on the discussion and analysis, the result reveals conclusion that religiosity has influence towards decision making to be a customer of Bank Riau Kepri Sharia, which means that increasing the religiosity influence the decision to be a customer of Bank Riau Kepri Sharia. The transformation of conventional consumer behavior theory, Kotler Armtrong to be Islamic consumer behavior.
\end{abstract}

Keywords: religiosity, customer decision, conventional consumer behavior theory, Islamic consumer behavior.

\section{Introduction}

Internationally, Islamic banking has become a global phenomenon marked by the increasing number of institutions related to Islamic finance[1]. The existence of Islamic banking brings universal moral values; justice, honesty, social care, ethics, morals and others as exemplified by Raslullāh shallallāhu 'alaihi wasallam[2], Plus the altruistic nature gives hope to the world that the financial industry will realize human values, not just economic man[1].

Over time, the international community has decided to become a customer of Islamic banking, resulting in the growth of Islamic banking at the global level so rapidly, it can be seen that the 
average growth of Islamic banking is more than $15 \%$ in a year, and has assets of more than U\$250 Million[3]. At the global level there are 10 countries that excel in developing Islamic finance; Kuala Lumpur-Malaysia, Manama-Bahrain, Dubai-UAE, London-United Kindom, Doha-Qatar, KuwaitKuwait, Karachi-Pakistan, Riyadh-Saudi Arabia, Jakarta -Indonesia, and Istanbul-Turkey[4].

The Asian level in the Islamic Finance Country Index (IFCI) data puts Malaysia in first place, even at the global level. While Iran is in the second tier, Saudi Arabia is in third place, the UAE and Kuwait are in fourth and fifth respectively. Meanwhile, Indonesia occupies the sixth position in the Islamic Finance Country Index (IFCI). Malaysia's position is the biggest for now. The difference in the ranking of each country is due to different management in the development of Islamic banking[5].

The decision to become a customer of Islamic banking is accepted in both western and European countries, not only Islamic countries. Since 2000 European countries have opened themselves to adopt the Islamic economy. Because the concept of Islamic economics has a clear system and purpose in dealing with various economic problems and social inequalities[6]. The atmosphere of sharia development was felt in 2004 after The Islamic Bank of Britain (IBB) was officially established as Europe's first Islamic bank[7]. The enthusiasm of the European community is high; it is proven that Islamic banking can compete with conventional banks in offering quality products to the public.Satria Dwi Saputro, "'Sejarah Dan Pertumbuhan Perbankan Syariah di Dunia'," Medan Bisnis Daily, Jendela Informasi Sumatera Utara, Universal Islāmic Economic UIN Sumatera Utara September (2015). The progress of Islamic banking is seen with assets reaching US \$ 18 million, making Islamic banking in the UK a place to invest for Muslims from rich Middle Eastern countries using sharia principles[9].

On a national scale, Indonesian Islamic banking continues to grow, especially after the enactment of law number 10 year $1998^{1}$ concerning banking. With this law, Indonesian Islamic banking has wider opportunities to develop, conduct business activities, including providing opportunities for conventional commercial banks to open branch offices that carry out banking operations based on sharia principles. Sharia banking law number 21 year $2008^{2}$ describes the operation of Islamic banking in accordance with Islamic teachings as a solution for the prohibition of usury ${ }^{3}$ and interest-free.

Regionally, the development of sharia banking in Tembilahan Kota seems to be declining due to a sharia bank which permanently closed its Sub-Branch Office. This can be seen in table 1. Below;

\footnotetext{
${ }^{1}$ Law of the Republic of Indonesia number 10 of 1998 concerning Amendments to Law number 7 of 1992 concerning Banking. Ratified in Jakarta On November 10, 1998, the President of the Republic of Indonesia, Bacharuddin Jusuf Habibie.

${ }^{2}$ Law of the Republic of Indonesia Number 21 of 2008, concerning Sharia Banking.

${ }^{3}$ al-Qur'an, 2: 275. Further explained in the verse 278-279.
} 
Table 1. Sub-Branch Office of Islamic bank Tembilahan Kota

\begin{tabular}{|cccccc}
\hline Sharia Bank & \multicolumn{5}{c}{ Year } \\
\cline { 2 - 6 } Tembilahan Kota & $\mathbf{2 0 1 6}$ & $\mathbf{2 0 1 7}$ & $\mathbf{2 0 1 8}$ & $\mathbf{2 0 1 9}$ & $\mathbf{2 0 2 0}$ \\
Bank Muamalat & 1 & - & - & - & - \\
Bank Riau Kepri Sharia & 1 & 1 & 1 & 1 & 1 \\
Bank Mandiri Sharia & 1 & 1 & 1 & 1 & 1 \\
Total & $\mathbf{3}$ & $\mathbf{2}$ & $\mathbf{2}$ & $\mathbf{2}$ & $\mathbf{2}$ \\
\hline \multicolumn{2}{r}{ Course: Otoritas Jasa Keuangan (OJK) } \\
\hline
\end{tabular}

Table 1 Shows the number of Islamic banking in 2016 (Bank Muamalat Indonesia, Bank Riau Kepri Sharia and Bank Mandiri Sharia), but in 2017 one of the three Islamic banks (Bank Muamalat Indonesia) permanently closed the Sub-Branch Office in Tembilahan Kota 'out of business'. On the other hand, conventional banking shows rapid development in Tembilahan Kota in 2016-2020. The addition of conventional banking occurred in 2018, BCA (Bank Central Asia) which is located on J1. M. Boya, Tembilahan Kota. Table 2. Below;

Table 2. Sub-Branch Offices of Conventional Banks, Tembilahan Kota

\begin{tabular}{|cccccc}
\hline Conventional Banks & \multicolumn{5}{c}{ Year } \\
\cline { 2 - 6 } BCA & $\mathbf{2 0 2 0}$ & $\mathbf{2 0 1 9}$ & $\mathbf{2 0 1 8}$ & $\mathbf{2 0 1 7}$ & $\mathbf{2 0 1 6}$ \\
Panin Bank & 1 & 1 & 1 & - & - \\
Bank Mega & 1 & 1 & 1 & 1 & 1 \\
Bank Danamon & 1 & 1 & 1 & 1 & 1 \\
Bank Riau Kepri & 1 & 1 & 1 & 1 & 1 \\
Mandiri & 1 & 1 & 1 & 1 & 1 \\
BTN & 1 & 1 & 1 & 1 & 1 \\
BNI & 1 & 1 & 1 & 1 & 1 \\
BRI & 1 & 1 & 1 & 1 & 1 \\
Total & 1 & 1 & 1 & 1 & 1 \\
\hline & $\mathbf{9}$ & $\mathbf{9}$ & $\mathbf{9}$ & $\mathbf{8}$ & $\mathbf{8}$ \\
\hline
\end{tabular}

The factors that influence consumer behavior - based on Kotler Armstrong's theory, especially religiosity - are all reflected in the life of the people in Tembilahan who have a tradition of prioritizing the values of togetherness with the principles of mutual cooperation and mutual help. 
Tembilahan tradition has the motto ${ }^{4}$ as 'Kota Ibadah, ${ }^{5}$ and 'Kota Santri, ${ }^{6}$ thick with traditions of tahlil, dhikr, istighosah and others, plus the geological condition which is nicknamed 'Negeri Seribu Parit',Tania Edna Bhakty dan Nur Yuwono, "Studi Pengendalian Kota Tembilahan Kabupaten Indragiri Hilir," Artikel, Universitas Janabadra dan Universitas Gadjah Mada (2018). is a reflection of the principles of life, religious values are the basic guidelines that animate real conditions naturally.

Demographically, the population of Tembilahan 2018 is 731,396 people[12] or 41,252 families, the majority of which are 95.88\% Muslim.Badan Pusat Statistik, Provinsi Riau dalam Jumlah Pemeluk Agama Menurut Kabupaten/Kota Dan Jenis (Update Terakhir: 24 Maret 2015, 2015). The development of Islamic banking in the global world is so rapid as well as nationally, but Islamic banking in Tembilahan has decreased where the majority of the people are Muslims, in contrast to conventional banking which is growing quite rapidly. Metawa and Almossawi[14] explain that the two most important criteria for selecting Islamic banks are loyalty to Islamic principles (religiosity), followed by the rate of return (profit).

Majelis Ulama Indonesia (MUI) issued a Fatwa regarding the prohibition of interest and the prohibition of conversing with Conventional Financial Institutions. ${ }^{7}$ World scholars such as Yūsuf Qordhowi in his book[15] explain a lot about the prohibition of usury and the wisdom of this prohibition. As a Muslim, you should stay away from usury, as the word of Allah subhanahu wata'ala forbids it (Al-Qur'an, 2: 275).

Based on the explanation above, the writer is interested to research, "The Influence of Religiosity toward Costumers 'Decision Making In Choosing Bank Riau Kepri Sharia Tembilahan

${ }^{4}$ The motto in this case is religious, namely as Kota Ibadah and Kota Santri. The motto is in accordance with Kotler Armstrong's theory which places religion as a sub-culture. John Saunders Philip Kotler, Gary Armstrong, Veronica Wong, Principles of Marketing, Fourth Eur. (Prentice Hall, 2005): 257.

${ }^{5}$ The motto widely known by the public so far is Tembilahan as Kota Ibadah in a Spiritual sense (ubudiyah), or even in a physical sense, Ibadah (Indah, Bersih, Aman, Damai dan Harmonis). In [36]

${ }^{6}$ Tembilahan as Kota Santri is widely known by the public, as evidenced by the sung Islamic song ' Kota Santri' in Tembilahan at the VII Riau Regional Sports Week, officially opened by the Governor of Riau, Rusli Zainal in Tembilahan, Saturday (15/10/11).

${ }^{7}$ Fatwa Dewan Syariah Nasional (DSN) Majelis Ulama Indonesia (MUI) in 2000 which stated that interest was not in accordance with sharia. Fatwa Majelis Ulama Indonesia, Number 1 of 2004 concerning Interest (Interest/Fa'idah) and the prohibition of mu'amalah with Conventional Financial Institutions. For areas that already have offices/networks of Sharia Financial Institutions and are easily accessible, transactions based on interest calculations are not allowed. For areas where there is no Sharia Financial Institution office/network, it is allowed to conduct transactions at conventional financial institutions based on the principle of dharurat/intention. The infrastructure in Tembilahan Kota has available offices/networks of Islamic Financial Institutions. 
Kota, Indonesia", (The Transformation of Conventional Consumer Behavior Theory, Kotler Armstrong).

\subsection{Problem Formulations and Objectives of Study}

Referring to the background of study, problem indification and limitation, problem formuations created in this research is as follows: Does religiosity influence decision making to be costumers of Bank Riau Kepri Shariah Tembilahan Kota, Indonesia?

\subsection{Theoretical Framework}

This study uses religiosity as a variable in the study. Religiosity as a religious commitment[16]. Religiosity is traditionally presented as a level of spiritual commitment[17], and is considered a derivative or component of religion[18]. In the literature there are several definitions of the construct of religiosity[19]. The intensity of one's religious beliefs is known as religiosity[20]. Religiosity refers to the extent to which beliefs in certain religious values and ideals are held and practiced by individuals[21]. Religiosity also reflects an individual's religious commitment to following his or her main beliefs[22], and it is a sub-category of human values and is specifically concerned with one's relationship with others.

Previous studies have shown that religiosity plays an important role in determining consumer attitudes and behavior[23]. However, other studies have not found a significant relationship between religiosity and customer attitudes and behavior. Usman et al[24] have stated that religiosity has no significant impact on the decision of Muslim consumers to choose Islamic banks.

Religion based on the opinion of Glock and Stark[25] states that religious is the level of individual conception of religion and the level of one's commitment to religion. The level of conceptualization is the level of a person's knowledge of his religion, and what is meant by the level of commitment is something that needs to be understood thoroughly, so that there are various ways for individuals to become religious.

According to Glock and Stark in Dadang Kahmad, ${ }^{8}$ the way of religion has five interrelated aspects, this is in accordance with the opinion of Al Abdulrazak, R. M., and Gbadamosi[26] and Hill et al[27]: The five aspects of religion are: 1) Religious belief, 2) Religious practice, 3) Religious feeling, 4) Religious knowledge and 5) Religious effect. This study will use the theory of Charles Y. Glock and Rodney Stark to measure the religiosity variable.

Several studies confirm that religiosity has an impact on the decision to become a customer. This is in accordance with the research of Kapriani, Yunus Zain, Osman Lewangka, Sanusi Fattah,Kapriani, Muh. Yunus Zain, Osman Lewangka, "The Influence of Religious Values, Social Factor and Service Quality In Individual Customer Decision Using Murabahah Financial on Islāmic

${ }^{8}$ Muhammad Sholikhin, Ritual dan Tradisi Islām Jawa, 1st ed. (Jakarta: Narasi, 2010). 444. 
Bank, Indonesia Vol. 3, Issue 12, (December 2014), ISSN 2277-8616." the results of the study show that religious values have a significant effect on psychological factors and beliefs, but religious values have an indirect effect on customer decisions. Shinta Arum Kusuma Wardani and Mudji Sabar[29] produced research that religiosity had an influence on decision making to become a customer of BNI Syariah North Jakarta. Fatma'sFatma, "Pengaruh Persepsi Religiusitas, Kualitas Layanan, Dan Inovasi Produk Terhadap Kepercayaan dan Komitmen Serta Loyalitas Nasabah Bank Umum Syariah Di Jawa Timur" (Universitas Airlangga, 2005). research found that religiosity had a significant positive effect between perceptions of religiosity and belief, the results of the study support the hypothesis that the higher the customer's perception of the "truth" of the application of Islamic values in Islamic banking operations, their trust in Islamic banking will increase. Nejdet Delener[31] explained that religions practiced in society affect the decision-making role of individuals, institutions and customs, and it has been argued that religious orientation has a strong influence on the development of family commitments in providing values that are oriented towards meeting needs and welfare and helping others.

\section{Methodology}

This research uses explanatory quantitative method to explain the relationship between one variable with another variable to test a hypothesis. The purpose of employing explanatory method is to explain the relationship between the variables of religiosity towards purchase decision variable. Independent variables used in this study is religiosity variable (X). Dependent variable used in this study is decision of becoming a custome of Bank Riau Kepri Shariah Tembilahan Kota (Y).

Population in this study is derived from all customers of Bank Riau Kepri Shariah Tembilahan Kota during the period of January - February 2021. Sampling method employed is purposive sampling therefore the total sample is determined to be 205 respondents. To determine the sample using multivariate analysis Jhon Hair (Joseph F. Hair, 2014). Hair recommends that the minimum sample size is 5 - 10 times the number of parameters estimated. In this research model, there are 41 items (estimated parameters), so the sample used is between $205-410$. The assumed sample size for SEM that must be met is at least 205. To answer the problems formulated in this study using Structural Equation Modeling (SEM) is conducted to find out the extent of independent variables of religiosity $(\mathrm{X})$ towards dependent variable which is purchase decision $(\mathrm{Y})$. 


\section{Results and Discussion}

\subsection{Result of Variabel}

The results of hypothesis testing in table 6. above, state that with a P value of 0.049 and C.R. of 1,966 exogenous variables of religiosity have a significant positive influence on the endogenous variable of the decision to become a customer with a standardized estimate coefficient value of 0.094. That is, the increase in the value of religiosity by one unit increases the decision to become a customer $9.4 \%$.

\subsection{Discussion}

Referring to the data analysis and findings conducted, the discussions in this study is elaborated as follows:

Religiosity has been proven to have an influence on the decision to become a customer of Bank Riau Kepri Shariah Tembilahan Kota

The results of this hypothesis explain that there is a significant effect of the direct relationship of the religiosity variable on the decision variable to become a customer. This is in line with the research of Kotler (1996), Shinta Arum Kusuma Wardani and Mudji Sabar (2019), Yudhi Herliansyah, Lucky Nugroho, Denanda Ardilla, Yananto Mihadi Putra (2019), James Sood Yukio Nasu (1995), Nittin Essoo \& Sally Dibb ( 2010), Syed Shah Alam, Rohani Mohd, Badrul Hisham (2011), Ahmad Saif-Alddin Abu-Alhaija, Raja Nerina Raja Yusof and Haslinda Hashim (2018), Rachmad Hidayat and Sabarudin Akhmad (2015), Safiek Mokhlis (2009), Stephen W. McDaniel and John J. Burnett (1990), Rika Yulianti, Marijati Sangen and Ahmad Rifan (2016).

But there are other studies that have not found a significant relationship between religiosity and customer attitudes and behavior, meaning that religiosity has no effect on decisions to become consumers, Usman et al.Usman, H., Tjiptoherijanto, P., Balqiah, T. E., \& Agung, "The Role of Religious Norms, Trust, Importance of Attributes and Information Sources in the Relationship between Religiosity and Selection of the Islāmic Bank." have stated that religiosity does not always have a significant impact on the decision of Muslim consumers to choose Islamic banks.

Further analysis, the value of loading factor and the average religiosity, the total score is 8390 , the total average is 4.0 , the whole percentage is $81.8 \%$. The loading factor of each item of the high value variable is above 0.62 and the results of the loading factor of the religiosity variable on the decision to become a customer is positive, the religiosity variable affects the public's decision to become a sharia banking customer. So it can be said that the religiosity variable has a significant effect on the decision to become a customer.

Data processing shows the standardized factor of the relationship of the religiosity variable to the decision variable to become a customer of 0.094 . This means that the religiosity of the respondents is an important reason for customers to choose Islamic banking. In other words, religiosity on the decision to become a customer has a direct effect, making a very meaningful 
contribution to the decision. Seeing the direct influence of the latent variable of religiosity on the decision variable to become a customer of 0.167 . This means that the direct influence of religiosity on the decision to become a customer is 0.167 which is a value that has a significant influence.

Religiosity has a significant influence on the decision to become a customer of Tembilahan Kota Syariah Banking. Religious people (Muslims) will tend to choose Islamic banking, "aduman Okumu" (2015). The lack of socialization of Islamic banking to the public causes a lack of understanding of Islamic banking, Nadia, et al (2019)[32], resulting in people preferring to be customers of conventional banking rather than Islamic banking, Annisa, et al (2015)[33].

Da'wah to educate the public is the key word and the best solution is to increase people's knowledge, to straighten and improve the wrong mindset of the people, Puspita, et al (2020) [34]. Educate the public about Islamic banking using language that is easily understood and accepted by the community. If the public's response to Islamic banking is that it is more expensive than conventional banking, then we can explain based on Raditya's opinion $(2021)^{9}$ that Islamic banking assets are still small compared to conventional banking which controls $80.66 \%$ of banking assets in Indonesia, OJK (2020). ${ }^{10}$

Syafi'i Antonio's opinion ${ }^{11}$ is that goods that have high quality and are comfortable to use must be more expensive than usual because these items are very special. Antonio continued that in fact Islamic banking is cheap but less exposed to media, more expensive parts that are widely exposed in the media.

Likewise, Islamic banking has a higher quality, which has been "designed" by scholars, Majelis Ulama Indonesia (MUI), Dewan Syariah Nasional (DSN), and Islamic banking experts. When people become customers of Islamic banking, it is guaranteed that their body and soul will feel calmer, more comfortable, safe and peaceful. Because based on the results of ijtihād MUI, DSN, Islamic banking experts and international scholars stated that Islamic banking is free from usury, because all transactions are based on contract (ijab-kabul).

This guarantee of peace of mind, body, security, comfort and halalness is what they are looking for. Islamic banking guarantees halalness because Islamic banking has gone through a very long ijtihād process (decades since the establishment of Islamic banking) carried out by scholars in the world and Islamic economic experts. This ijtihād guarantees peace of mind and body and lawfulness because Ijtihad is one of the sources of Islamic law after the Qur'an and al-Hadith.

There is nothing wrong with the results of ijtihad. If there is a mistake, there is still one reward and the person who does it is not guilty of the mistake of ijtihād (the error is revised with the results of the next ijtihād decision). If ijtihad is correct, you will get two rewards. Al-Ḥadīth Rasūlullāh shallallāhu 'alaihi wasallam; From Amr ibn al-'Ash: That he heard the Messenger of Allah sallallāhu

${ }^{9}$ Raditya Sumana (UNAIR), (2021).

${ }^{10}$ Otoritas Jasa Keuangan, Laporan Profil Industri Perbankan, Triwulan I (2020). 22.

${ }^{11}$ Muhammad Syafi'i Antonio, in FESyar 2019, Grand City Mall Surabaya, (2019). 
'alaihi wasallam say: "If a judge judges and finds out he is right, then he gets two rewards, and if a judge judges and makes ijtihad then he is wrong, for him one reward." (Bukhari: 6805).

The phenomenon of the Tembilahan community, where the majority of Muslims choose conventional banking, is less likely to choose Islamic banking due to the lack of socialization of Islamic banking to the public, Ahmad Fauzan (2021).

\section{Conclusions}

\subsection{Conclusions}

Based on the result of research and discussion conducted, that's conclusions may be drawn as follows: Religiosity provides influence towards decision making of becoming a customer of Bank Riau Kepri Sharia Tembilahan Kota, There is a positive and significant influence between the religiosity variable on the decision to become a customer of Bank Riau Kepri Syariah Tembilahan Kota. These results provide support for the hypothesis in this study. This means that the high religiosity of the community, the high decision to become a customer of Bank Riau Kepri Syariah. Religiosity has simultaneously, which means the changes in variables of religiosity also change the decision making to be a customer of Bank Riau Kepri Sharia Tembilahan Kota.

\subsection{Implication Theory}

Transformation of Conventional Consumer Behavior Theory to Islamic Consumer Behavior Theory (Sharia).

This research is the development of Kotler-Armstrong theory regarding consumer behavior. Kotler discusses that consumer behavior is influenced by four variables, namely culture, psychology, personal and social. The existence of religion is still placed in sub-culture. Here the researcher finds a weakness in the theory. Where consumer behavior should be influenced by five variables, namely religion, culture, psychology, personality and social. Religion is a separate variable not included in the sub-culture. 


\section{References}

[1] N. Kholis, "Potret Perkembangan Dan Praktik Keuangan Islam Di Dunia," Millah J. Stud. Agama, Univ. Indones., vol. Vol. XVII, no. 1, p. 1, 2017, doi: 10.20885/millah.vol17.iss1.art1.

[2] A. Gafur, "Analisis Faktor Yang Memengaruhi Perilaku Pedagang Etnik Tionghoa Dalam Memanfaatkan Jasa Bank Syariah," At-Taradih, Fak. Syariah dan Ekon. Islam IAIN Antasari., vol. 53, no. 9, p. 9, 2013, doi: 10.1017/CBO9781107415324.004.

[3] A. S. J. dan M. Iqbal, "Analisis Perbandingan Kinerja Keuangan Perbankan Syariah Dengan Perbankan Konvensional,” J. Episteme Inst. Perbanan Jakarta., vol. 7, no. 2, p. 350, 2012.

[4] A. A. Musyafah, "Perkembangan Perekonomian Islam di Beberapa Negara di Dunia," Diponegoro Priv. Rev. Univ. Diponegoro., vol. 4, no. 1, p. 421, 2019.

[5] H. R. dan N. Mubriyanto, “'Dampak Penerapan Perbankan Syari’ah Terhadap Pertumbuhan Ekonomi Negara: Kajian Perbandingan Malaysia dan Indonesia (The Effect of Islamic Banking on Economic Growth: Comparative Evidence Malaysia and Indonesia)," Penelit. Kompetitif UIN STS Jambi 2016, p. 87, 2016.

[6] L. K. Akmalia Qurrota A’yun, "Penerapan Ekonomi Islam Sebagai Solusi Mengatasi Kesenjangan Sosial," Proseding Semin. Nas. ASBIS 2017, Politek. Negeri Banjarmasin., p. hal. 34., 2017.

[7] A. Malik, M. S. Malik, and H. Shah, "An analysis of Islamic banking and finance in west: From lagging to leading," Asian Soc. Sci., vol. Vol. 7, no. 1, p. 181., 2011, doi: 10.5539/ass.v7n1p179.

[8] S. D. Saputro, "Sejarah dan Pertumbuhan Perbankan Syariah di Dunia'," Medan Bisnis Daily, Jendela Inf. Sumatera Utara, Univers. Islam. Econ. UIN Sumatera Utara, vol. September, 2015.

[9] Aisyah, "'Perkembangan Perbankan Syariah di Inggris"," IBEC FEBUI, Fak. Ekon. dan Bisnis, Univ. Indones. Depok, p. 1, 2017.

[10] Otoritas Jasa Keuangan, Statistik Perbankan Syariah (SPS). Jakarta: OJK, 2020.

[11] T. E. B. dan N. Yuwono, "Studi Pengendalian Kota Tembilahan Kabupaten Indragiri Hilir," Artik. Univ. Janabadra dan Univ. Gadjah Mada, 2018.

[12] B. P. Statistik, Kabupaten Indragiri Hilir Dalam Angka 2019. Indragiri Hilir Regency in Figures. BPS Kabupaten Indragiri Hilir, Katalog/Catalog: 1102001.1403, 51, 2019.

[13] B. P. Statistik, Provinsi Riau dalam Jumlah Pemeluk Agama Menurut Kabupaten/Kota dan Jenis. Update Terakhir: 24 Maret 2015, 2015.

[14] S. M. dan M. Almossawi, "Banking behavior of Islamic bank customers: Perspectives and implications," Int. J. Bank Mark., vol. 16, no. 7, pp. 299-313, 1998.

[15] A. S. S. Q. dan S. M. Yusuf Qordhowi, Haruskah Hidup Dengan Riba (Arbahul bunuk bainal halal wal haram Tafsiru Aayaatir riba), Edisi Pert. Jakarta: Gema Insani Press, 1991.

[16] S. Essoo, N., \& Dibb, "The role of Islamic culture in service quality research," Asian J. Qual., vol. 12, no. 1, 2004, doi: http://doi.org/10.1362/0267257041838728.

[17] J. J. McDaniel, S. W., \& Burnett, "Consumer religiosity and retail store evaluative criteria," J. Acad. Mark. Sci., vol. 18, no. 2, pp. 101-112, 1990, doi: http://doi.org/10.1007/BF0272642.

[18] N. Abou-Youssef, M. M. H., Kortam, W., Abou-Aish, E., \& El-Bassiouny, "Effects of religiosity on consumer attitudes toward Islamic banking in Egypt," Int. J. Bank Mark., vol. 33, no. 6, pp. 786- 807, 2015, doi: http://doi.org/10.1108/JFM-03-2013-0017.

[19] R. Barhem, B., Younies, H., \& Muhamad, "Religiosity and work stress coping behavior of Muslim employees," Educ. Bus. Soc. Contemp. Middle East. Issues, vol. 2, no. 2, pp. 123-137, 2009, doi: http://doi.org/10.1108/17537980910960690. 
[20] M. Mukhtar, A., \& Mohsin Butt, "Intention to choose Halal products: the role of religiosity," J. Islam. Mark., vol. 3, no. 2, pp. 108-120, 2012, doi: http://doi.org/10.1108/17590831211232519.

[21] N. Delener, "The Effects of Religious Factors on Perceived Risk in Durable Goods Purchase," J. Consum. Mark., vol. 7, no. 3, pp. 27-38, 1990, doi: http://doi.org/10.1108/EUM0000000002580. [22] J. Mathur, A., Barak, B., Zhang, Y., Lee, K. S., Yoo, B., \& Ha, "Social religiosity: concept and measurement across divergent cultures," Asia Pacific J. Mark. Logist., vol. 27, no. 5, pp. 717-734, 2015, doi: http://doi.org/10.1108/APJML-10-2014-0144.

[23] M. A. Tariq, M., \& Khan, "Offensive advertising: a religion based Indian study," J. Islam. Mark., vol. 8, no. 4, pp. 656-668, 2017, doi: http://doi.org/10.1108/JIMA-07-2015-0051.

[24] I. G. N. Usman, H., Tjiptoherijanto, P., Balqiah, T. E., \& Agung, "The role of religious norms, trust, importance of attributes and information sources in the relationship between religiosity and selection of the Islamic bank," J. Islam. Mark., vol. 8, no. 2, pp. 158-186, 2017, doi: http://doi.org/10.1108 JIMA-012015-0004.

[25] C. Y. G. and R. Stark, Religion and Society in Tension. McNally, 1971.

[26] A. Al Abdulrazak, R. M., \& Gbadamosi, "Trust, religiosity, and relationship marketing: a conceptual overview of consumer brand loyalty," Soc. Bus. Rev., vol. 12, no. 3, pp. 320-339, 2017, doi: http://doi.org/10.1108/SBR-03-2017-0014.

[27] G. Arnould, E., Price, L. \& Zikhan, Consumers, 2nd ed. New York: McGraw-Hill, 2004.

[28] S. F. Kapriani, Muh. Yunus Zain, Osman Lewangka, "The Influence of Religious Values, Social Factor and Service Quality In Individual Customer Decision Using Murabahah Financial on Islamic Bank, Indonesia Vol. 3, Issue 12, (December 2014), ISSN 2277-8616.," Int. J. Sci. Technol. Res., vol. 3 , no. $12,2014$.

[29] S. A. K. W. dan M. Sabar, "The Influence of Religiosity, Corporate Image and Service Quality towards Decision Making of Becoming a Customer of Bank BNI Syariah Jakarta Utara," Int. J. Innov. Sci. Res. Technol., vol. 4, no. 7, pp. 1202-1208, 2019.

[30] Fatma, "Pengaruh Persepsi Religiusitas, Kualitas Layanan, dan Inovasi Produk Terhadap

Kepercayaan dan Komitmen Serta Loyalitas Nasabah Bank Umum Syariah di Jawa Timur," Universitas Airlangga, 2005.

[31] N. Delener, "Religious Contrasts in Consumer Decision Behaviour Patterns: Their Dimensions and Marketing Implications," Eur. J. Mark., vol. 28, no. 5, pp. 36-53, 1994.

[32] S. Nadia, A. Ibrahim, and Jalilah, "Analisis Hambatan Pertumbuhan Perbankan Syariah di Indonesia (Kajian Terhadap Perbankan Syariah di Aceh),” J. Jihbiz, vol. 1, no. 2, 2019.

[33] L. N. Annisa and R. Yaya, "Pengaruh Dana Pihak Ketiga, Tingkat Bagi Hasil dan Non Performing Financing Terhadap Volume dan Porsi Pembiayaan Berbasis Bagi Hasil Pada Perbankan Syariah di Indonesia," J. Share, vol. 4, no. 1, 2015.

[34] P. Handayani, Y. Purwanti, and N. Q. S. Nirwana, "Edukasi Kemandirian Ekonomi Perempuan Sebagai Basis Dakwah Aisyiyah,” 2020.

[35] J. S. Philip Kotler, Gary Armstrong, Veronica Wong, Principles of Marketing, Fourth Eur. Prentice Hall, 2005.

[36] "Bupati Wardan Ingin Tembilahan Jadi Kota 'Ibadah","” Artikel, bertuahpos.com, 2016.

[37] M. Sholikhin, Ritual dan tradisi Islam Jawa, 1st ed. Jakarta: Narasi, 2010. 